\title{
Yabancı Coğrafyada Konut Talebinin Sosyal ve Ekonomik Etkileri: Trabzon Örneğiं*
}

\author{
Social And Economic Effects of Housing Demand in Foreign Geography: Trabzon
}

\author{
Ceren ÜNLÜ ÖZTÜRK ${ }^{1} \oplus$, Zeynep YILMAZ BAYRAM ${ }^{2} \odot$
}

${ }^{1}$ Arş. Gör, Karadeniz Teknik Üniversitesi, Mimarlık Fakültesi Şehir ve Bölge Planlama Bölümü, Trabzon, Türkiye

${ }^{2}$ Dr. Öğr. Üyesi, Karadeniz Teknik Üniversitesi, Mimarlık Fakültesi Şehir ve Bölge Planlama Bölümü, Trabzon, Türkiye

ORCID: C.Ü.Ö 0000-0003-1619-1510; Z.Y.B. 0000-0001-6751-4258

\section{öz}

Birinci konuttan daha kısa sürelerle ve genellikle rekreasyonel amaçlı kullanılan ikinci konutların sahipliliği, ulaşım ve iletişim teknolojilerinde yaşanan gelişmelerle ve ulus devletlerin yasalarına bağlı olarak uluslararası düzeye taşınmıştır. Bu durum kentlerin ekonomik ve sosyal yapılarını olumlu ve olumsuz yönde etkilemiştir. Türkiye'deki mevzuatta, 2012 yılında farklı ülke vatandaşlarının taşınmaz edinimini belirleyen karşılıklılık ilkesinin kaldııılmasıyla, ülkemizde konut edinen yabancıların uyruklarında ve tercih ettikleri şehirlerde bu tarihten öncesine göre farklılaşmalar olmuştur. Trabzon'da 2012 yılı sonrasında yabancıların ikinci konut talep ettikleri ve edindikleri kentlerden biri olmuştur. Bu çalışmada ülkemizde yabancıların ikinci konut ediniminin 2012 yılı sonrasında, kentlerin sosyal ve ekonomik yapısına etkilerini Trabzon üzerinden belirlemektir. Konut sahibi yabancılar ve onlara konut arzını gerçekleştiren inşaat firmaları ile olmak üzere iki anket çalışması yapılmıştır. Arap coğrafyası vatandaşlarının Trabzon'da ikinci konut tercihlerinde, kentin fiziksel ve sosyal özelliklerinin olumlu etkisi bulunmaktadır. Trabzon'da yerel halkın yabancılar ile farklı alanlarda yaşama isteği ve artan konut fiyatlarının yerlilerin alım gücünü azaltması olumsuz etkiler arasında öne çıkmaktadır. Bu bağlamda yerel yönetimlerin konut politikalarında bu olumsuzlukları giderici kararlar alması önemlidir. Kentsel aktörlerin yabancıların konut talebinin, kentlere olası olumlu etkilerini arttırıcı ve olumsuz etkilerini bertaraf edici şekilde yönlendirmeleri gerekir.

Anahtar kelimeler: Yabancıların İkinci Konut Talebi, Araplar, Sosyal ve Ekonomik Etkiler

\section{ABSTRACT}

The ownership of second homes has moved to the international level due to developments in transportation technologies and the laws of nation states. This has affected cities both positively and negatively. In 2012, the principle of reciprocity, which governs the acquisition of immovable property by citizens of different countries, was abolished in Turkey. Post this, there has been a differentiation in the nationalities of foreigners who purchase housing properties in Turkey and in their preferred cities. After 2012, Trabzon was one city where foreigners mostly bought homes. This study determines the effects of the second housing demand of foreigners on the social and economic structure of cities through Trabzon. Two surveys were conducted with foreigners who own homes and construction companies that supply housing to them. The results show that the physical and social characteristics of the city have a positive effect on the second housing demands of Arabs. The willingness of local people to live in different areas with foreigners and increased house prices stand out among the negative effects. Urban actors should direct the housing demand of foreigners in a way that increases the positive effects and eliminates the negative ones.

Keywords: Second Housing Demand of Foreigners, Arabs, Social and Economic Effects

*Bu çalışma, Dr. Öğr. Üyesi Zeynep Yılmaz Bayram danışmanlığında Ceren Ünlü tarafından hazırlanan “Yabancıların İkinci konut Arz-Talebinin Kentlere Etkisi: Trabzon Örneği" isimli Yüksek Lisans Tezi' nin bir bölümünden üretilmiştir.

Başvuru/Submitted: 24.02.2021 • Revizyon Talebi/Revision Requested: 19.04.2021 • Son Revizyon/Last Revision Received: 23.04 .2021 • Kabul/Accepted: 11.05 .2021

Sorumlu yazar/Corresponding author: Zeynep YILMAZ BAYRAM / zeynepyilmaz@ktu.edu.tr

Atıf/Citation: Unlu Ozturk, C., Yilmaz Bayram, Z. (2021). Yabancı coğrafyada konut talebinin sosyal ve ekonomik etkileri: Trabzon örneği. Cografya Dergisi, 42, 181-194. https://doi.org/10.26650/JGEOG2021-886312 


\section{EXTENDED ABSTRACT}

Second homes are used for shorter periods of time than first homes and are often considered for recreational purposes. With technological developments, increase in transportation possibilities, and legal permissions of nation states, the ownership of a second home has shifted to an international level. Previous studies have determined that location, urban experiences, costs, international relationships, and legal regulations are effective in the second housing demands of foreigners. There are positive and negative economic and social effects on cities where foreigners buy second homes. In order to control and direct demand at the international level, the characteristics of the demand and its social and economic effects on cities must be determined.

In 2012, the principle of reciprocity governing which citizens of a country can buy immovable property was abolished in Turkey. Post this, there were differences in the nationality of foreigners who bought housing properties in Turkey and in their preferred cities. There were limited studies with regards to the process of purchasing housing properties in Turkey post 2012. In this context, this study aims to determine the characteristics of the demands of foreigners who have bought housing properties in Turkey after 2012 and their social and economic impact on cities. There are two important reasons for choosing Trabzon as the field of study. First, Trabzon was among the top 10 cities in Turkey that foreigners considered for second home buying as of 2014. Second, foreigners who bought the most single spaces in the province were citizens of Arab countries who had gained the right to buy property after 2012.

For the purpose of this study, two surveys were conducted; one with foreigners who own houses in the city and the other with construction companies developing housing projects in the city. In the survey administered to foreigners, the aim was to determine the social and demographic structures, reasons for the housing demand in Trabzon, their experiences in the city, reasons for the second housing preferences, and characteristics of the houses. The number of foreigners (universe size) who had single spaces in the province registered with the General Directorate of Land Registry Cadastre (2017) was determined to be 1762 . With a $95 \%$ trust level $\pm 10 \%$ sampling margin, the sample was calculated as $\mathrm{n}=60$ people. This face-to-face survey was prepared in Turkish and translated into Arabic; the participants were selected using the simple incidental sampling method. With the survey administered to the construction companies, the study determined the differences between the housing demands of domestic and foreign customers, their distribution in the urban geography, and their effects on the city. The group sampling method was used while determining the methods of this survey. According to the results of the survey conducted with foreigners, it was determined that they usually purchased housing in gated communities in the city that they had seen from construction companies and the internet. Of the 37 companies that produce such houses in the city, 14 companies that were reached and wanted to participate in the survey were queried face-to-face. Both survey forms had multiple choices and open- and closed-ended questions. Data obtained were analyzed descriptively using the SPSS program.

The findings of the survey were collected under three main headings: demographic characteristics of foreigners, causes and characteristics of foreigners' second housing demand, and social and economic effects of foreigners' second housing demand on cities. Arabs have a minimum of one and maximum of eight children, and the average household size is 4.6. They are married, are working, and have an education level of university and above. It was determined that these people came to Trabzon as tourists and bought housing in Trabzon, and found the services of the city generally sufficient. A majority of foreigners expressed their interest in settling in the city and would advise other foreigners to buy housing properties in the city. This is an indication that the demand for housing by foreigners will continue in the city. It was seen that the physical and social characteristics of the city are positively effective compared to other characteristics in the context of Arabs' second housing demand from the city. The desire of locals to be separated from foreigners in their living spaces, rising housing prices, and decreasing tourism income emerged as the main social and economic effect.

It is important that local governments, which produce housing policies and plan housing areas, implement decisions to address the negative effects created by the demand at the international level. Urban actors should direct the second housing demand of foreigners in a way that increases the possible positive effects and eliminates the negative ones. It is critical for local authorities to pay attention to these factors in the housing supply to increase the housing demand of foreigners. 


\section{GÍRIŞ}

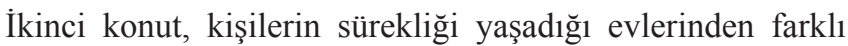
olarak dinlencelerinde ya da kısa süreli gezilerinde kullandıkları konut olarak tanımlanmaktadır (Keleş, 1998). Bunların kullanım süresi, sıklığı, işlevleri ve konumları hane halklarının sürekli yaşadığı konutlardan farklıdır. Genellikle deniz, göl, akarsu kenarları, yayla ve dağ gibi doğal nitelikleri yüksek bölgelerde bulunan bu tür konutlar, çoğunlukla insanların eğlenme, dinlenme, tatillerini geçirme gibi rekreatifamaçlı kullanılmaktadır (Bakırc1, 2007; Gündüz, 2003; Karaaslan ve Ercoşkun, 2005; Mizan, 1994, Yıldırım, 1992). Konutlar, insanların en temel ihtiyaçlarından biri olan barınma gereksinimlerinin karşılandığ1 yerler olmaları nedeniyle başka bir nesneyle ikame edilemezler. Bu özelliklerinden dolayı, konut talebi ve arzı hem yerel hem de merkezi yönetimler açısından önemli bir konudur. Konut talebi yasalar, yönetmelikler, merkezi ve yerel yönetimin konut politikaları, kentsel aktörler, vb. tarafından yönlendirilmektedir. Konut talebi ise, nüfus artışı, aile yapısında meydana gelen değişiklikler, kentleşme, sosyal ve kültürel gelişmeler, gelir seviyesi, sosyal talep ve yenilenme ihtiyac1 etmenlerine bağlı olarak oluşmaktadır (Sürmeli, 2003).

İkinci konutun tarihsel süreçteki gelişimine bakıldığında, 1980'li y1llar öncesinde ulusal düzeyde, genellikle metropoliten kentlerin çeperlerinde inşa edildikleri görülmektedir. Ancak bu tarihtenitibaren, teknolojide, üretimvetüketimalışkanlıklarındaki değişimler ve gelişimler ikinci konut sahipliliğinin uluslararası düzeye taşınmasına zemin hazırlamıştır. Teknolojik gelişmeler ile ulaşım bağlamında fiziksel mesafeler zamansal olarak kısalmıştır (Urry, 2000). Harvey (2008)'in "zaman mekân sıkışması" kavramında da küreselleşme ve kapitalizmin etkisiyle uzaklıkların azaldığı hissinin oluştuğunu belirtmektedir. Bunun sonucu olarak, uluslararası düzeyde insan, bilgi, sermaye ve mal hareketliliği artmıştır (Tomlinson, 2013).

Castles ve Miller (1993) yaşadığımız dönemi "Göç Çağı" olarak adlandırılmaktadır. Birleşmiş Milletler'in 2002 yılı Uluslararası Göç Raporu'nda dünya nüfusunun üçte birinin (yaklaşı 175 milyon insan) doğduğu ülkeden farklı bir ülkede ikamet ettiği belirtilmektedir. Küresel düzeyde yaşanan göç hareketleri itme ve çekme faktörleri üzerinden açıklanmaya ve çözüm bulunmaya çalışılmaktadır. Ekonomik istikrarsızlıkla, toplumsal ve siyasal çatışma itici faktörlerin başında gelirken; daha iyi yaşama ve çalışma olanakları ise çekici faktörler arasında öne çıkmaktadır (Giddens, 2012; Okyavuz, 2005). İnsanların vatandaşı olmadıkları bir ülkede ikinci konut edinimi, küresel düzeyde mevsimsel göç şeklinde deneyimlenmektedir (Bell ve
Ward, 2000). Ancak, uluslararası düzeyde göçü tetikleyen gelişmelerin yaşandığı ülkelerin vatandaşları için başka bir coğrafyada sahip olunan ikinci konutlar, kalıcı göçe kaymaları için atlama taşı olarak işlev görebilmektedir (Bakırcı, 2007).

Küreselleşme süreciyle birlikte uluslararası düzeye taşınan ikinci konut ediniminde insanların farklı coğrafyalarda konut talepleri üzerine yapılan araştırmalarda konumun, kentle ilgili deneyimlerin, uluslararası göçü tetikleyen olayların, maliyetlerin, uluslararası düzeyde ekonomik, siyasal ve toplumsal bağlantıların ve yasal düzenlemelerin etkili olduğunu ortaya koyulmaktadır (Casado-Diaz, 1999; Hall ve Müller, 2004; King, Warnes ve Williams, 1998; O’Reilly, 2001; Rodriguez, FernandezMayoralas ve Rojo, 1998).

Yabancıların ikinci konut talebini etkileyen etmenler arasında, suya ve yeşile yakınlık, doğanın içinde yer almak ve bölgenin iklimi öne çıkmaktadır (Casado-Diaz, 1999; King vd., 2000; O’Reilly, 2001 ve Rodriguez, 2001). Yapılı çevrenin ve yerel halkın da yabancıların talebi üzerinde etkisi bulunmaktadır. Onlar ikinci konut edinirken, o bölgede daha önce konut edinmiş olan yabancıların yaşadıkları yerleri, tanıdıkları ve akraba oldukları insanlara yakın olmayı tercih etmektedirler (Casado-Diaz, 1999).

Yabancıların daha önce tatil amacıyla turist olarak gittikleri ve beğendikleri bölgelerde konut edindikleri görülmektedir (Bakırcı, 2007). Onların, çalışma ve iş bağlantılarının olması da taleplerini olumlu yönde etkilemektedir. Uluslararası düzeyde devletin bu bağlantıları geliştirmeye yönelik politikaları da talebi artırmaktadır (Nudralı, 2007). Birinci konutun yer aldığı ülkeye kıyasla daha ucuz yaşam maliyetine sahip olan yerlerde ve gelişmiş ülkelere kıyasla zayıf para piyasaları bulunan gelişmekte olan coğrafyalarda daha ucuz konut fiyatları buralarda ikinci konut talebinin oluşmasına ve artmasına neden olmaktadır (Erdoğanaras, Güzey, Görer Tamer ve Yüksel, 2005).

İkinci konutun uluslararası düzeye taşınmasındaki diğer önemli bir faktör de, devletlerin izlediği politikalar ve yasal düzenlemelerdir. Hangi ülke vatandaşlarının, nereden ve ne kadar mülk alabileceğini ulus devletlerin yasalarıyla belirlenmektedir (Erdoğanaras vd., 2005; Hall ve Müller, 2004). Yabancıların konut ediniminde ulus devletlerin yasaları yer ve miktar bakımından esnek olması, talebin artmasında etkili olmaktadır (Bakırc1, 2007).

Türkiye'de yabancıların konut edinimini etkileyen yasal düzenlemeleri üç gruba ayırmak mümkündür: 1. Yabancıların konut edinimindeki mülkiyet haklarını kişi, yer ve miktar 
bakımından belirleyen yasalar, 2. Yabancıların konut talebi üzerinde etkili olan, uluslararası çalışma bağlantılarını, ortaklıklarını ve yatırımlarını etkileyen ve tüzel kişilerin taşınmaz edinimini düzenleyen yasalar, 3. Yabancıların konut satın alma süreçlerinin resmi işlemlerini, yabancıların hareketini ve ülkemizdeki ikamet şartlarını belirleyen düzenlemeler.

Türkiye'de yabancıların konut edinimini açısından, 1923'ten 1980'li yıllara kadar geçen sürede sınırlılıkların daha fazla olduğu görülmektedir. 1980'li yıllardan itibaren yasal düzenlemelerle hem tüzel kişilerin hem de gerçek kişilerin taşınmaz edinimindeki kısıtlılıkları esneten bir tutum izlenmiştir. Yabancıların ikinci konut edinimi açısından "karşşlıklılık ilkesi”nin tanıdığı esneklikler veya sınırlılıklar talebi doğrudan etkilemektedir. Karş1lıklılık ilkesi, en az iki devlet arasında uygulanan ve devletlerin birbirlerinin vatandaşlarına aynı ya da benzer mahiyette haklar tanımalarını belirtmekte ve mütekabiliyet ilkesi olarak da ifade edilebilmektedir (Çelikel, 2017). Bu ilke ilk anayasadan itibaren kanunlarımızda yer alırken, 1984 ve 1986 yılları arasında yürürlükten kaldırılmasına yönelik teşebbüsler olmuştur ve 2012 yılında ise kaldırılmıştır. 2012 yılı öncesinde 54 ülke ile Türkiye arasında karşıllklılık ilkesi bulunmaktaydı. Bu tarihten sonra, Bakanlar Kurulu'na, vatandaşı konut edinebilecek ülkeleri belirleme yetkisi verilmiştir ve yaklaşı 184 ülkenin vatandaşlarına Türkiye'de taşınmaz edinme hakkı tanındığı görülmektedir (URL-1 ve URL-2, 2012).

Türkiye'de yasal düzenlemelerdeki gelişmelere paralel olarak, 2012 yılı öncesinde ve sonrasında taşınmaz edinen yabancıların uyruklarında değişiklikler meydana gelmiştir. Bu tarihten önce yabancıların konut edinimine yönelik, satın alınan bağımsız bölümler şeklinde veri toplanmış ve değerlendirmelerde bunlar kullanılmıştır. 2012 yılı öncesinde ülkemizde Almanya, İngiltere ve Hollanda başta olmak üzere Avrupa Birliği üyesi ülke vatandaşları bağımsız bölüm edinmiştir (Tamer Görer, Erdoğanaras, Güzey ve Yüksel, 2006). 2015 yılından itibaren yabancıların uyruklarına göre konut satış istatistiklerine yönelik veri oluşturulmaya başlanmıştır. Bunlar incelendiğinde, en fazla konut edinen ilk on ülke içerisinde, sadece iki Avrupa Birliği ülkeleri (Almanya ve İngiltere) vatandaşları yer alırken, dört tane Arap ülkeleri (Irak, Suudi Arabistan, Kuveyt, Ürdün) vatandaşları bulunmaktadır (TÜIK, 2021). Belirtilen tarihten önce Türkiye'de taşınmaz edinimi için izni bulanmayan Arap ülkeleri vatandaşlarının, karşılılık ilkesinin kaldırılmasıyla ülkemizde konut edinmeyi tercih ettiklerini görmekteyiz. Ülkemizde konut edinen yabancıların uyruklarının değişmesi beraberinde ikinci konutların ülkemiz coğrafyası içerisindeki konumlarını da çeşitlendirmiştir.
2012 yılından önce Ege ve Akdeniz Bölgeleri'ndeki iller (Antalya, Aydın, Muğla, İzmir, Mersin) başta olmak üzere Marmara Bölgesi'nden birkaç ilde (İstanbul, Bursa) yabancılar çoğunlukla ikinci konut tercih edilmekteydi (Tamer Görer vd.,2006). 2012 yılından sonra ise; Karadeniz Bölgesi'nde Trabzon'un yabancilar tarafindan konut edinilen yerler arasında ilk sıralarda yer aldığını görmekteyiz. Benzer şekilde Marmara Bölgesi'nden Yalova ve Sakarya da en çok tercih edilen ilk on il arasına girmiştir (TÜiK, 2021).

Ülkemizde yabancıların konut edinimine yönelik çalışmalar yapılmıştır. Karakaya ve Turan (2006) tarafindan Didim'e emekli yabancıların göçü ve bunun kente ekonomik etkileri inceleyen çalışmada; ilçede ikinci konut edinen yabancıların genellikle İngiltere vatandaşı, 55 yaş ve üzeri oldukları tespit edilmiştir. Nudralı (2007)'nın çalışması da Didim'e yabancıların göçü ve deneyimleri üzerinedir. Her iki çalışmada da yabancıların özellikleri benzerlik göstermektedir. Bakırcı (2007) yabacıların ikinci konut edinimin fiziksel çevreye olan etkilerini Dalyan üzerinde sorguladığı çalışmasında, kentteki yabancıların genellikle İngiltere ve Almanya vatandaşı, 50 yaş ve üzerinde, emekli, yüksek eğitim düzeyine sahip olduklarını tespit etmiştir. Avcı vd. (2008), Fethiye'de yabancı göçü ve ikinci konut gelişimi arasındaki ilişkiyi araştırdıkları çalışmada, burada konut edinen yabancıların İngiltere ve Almanya uyruklu, 55 yaş ve üzerinde ve eğitim düzeyi yüksek oldukları belirtilmiştir. Tamer Görer vd. (2006) tarafından Alanya'da emekli yabancı göçü ve bunun etkilerinin analiz edildiği çalışmada, ikinci konut edinen yabancıların genellikle Almanya ve Hollanda vatandaşı, 50 yaş ve üzerinde ve emekli oldukları tespit edilmişsir.

Ülkemizde yabancıların ikinci konut edinimine yönelik çalışmalarda fiziksel, ekonomik ve sosyal etkiler, yabancıların deneyimleri ve göç gibi farklı konularının ele alındığı görülmektedir. Bunların ortak özelliği, sözü edilen yabancıların Avrupa Birliği üyesi ülkelerin vatandaşları olması ve Ege ile Akdeniz Bölgeleri'nin tatil beldelerinde gerçekleşmesidir. Bu bağlamda çalışma, 2012 sonrasında ülkemizden konut edinen Arap ülkeleri vatandaşları yabancılara yönelik olması ve Karadeniz Bölgesi'nde yer alan bir kentte gerçekleşmesi bakımından diğer araştırmalardan farklılaşmaktadır.

\subsection{Yabancıların ikinci konut ediniminin kentlere etkileri}

Yabancıların ikinci konut talebine yönelik gerçekleştirilen konut arzının, kent coğrafyasında sosyal, ekonomik ve mekânsal açıdan olumlu ve olumsuz etkileri olmaktadır. Clawson ve Knetsch (1966)'e göre yabancıların ikinci konut ediniminin 
ekonomik etkileri, anavatanlarında başlayıp, yeni yerleşilen alanda devam etmektedir. Ekonomik açıdan olumlu etkilerden ilki, uluslararası düzeydeki ikinci konutların birinci konutlar ile arasındaki mesafe fazla olduğundan ikinci konutlar kullanılırken ihtiyaç duyulan malların ve hizmetlerin gidilen ülkede karşılanmasıyla birlikte gidilen ülkeye yüksek gelirler bırakmasıdır (Bohlin, 1982). Bankacılık, emlak satışı, zanaat, perakende ticaret gibi birçok farklı malların ve servislerin üretilmesinde istihdam yaratılmaktadır. Ayrıca, gidilen ülke ve kentte alınan vergiler de yerel ve merkezi yönetimlere katk1 sağlamaktadır. Türkiye'de Didim'deki ikinci konutların vergilerinin kent ekonomisine olumlu etkisi olduğu tespit edilmiştir (Karakaya ve Turan, 2006; Nudral1, 2007). Yabancıların ikinci konut ediniminin ekonomik açıdan olumsuz etkileri genel olarak üç konu da yoğunlaşmaktadır. Bunlardan ilki, ikinci konutlara dair sağlanan ilave altyap1 ve servislerin yarattığ1 maliyetlerdir (Forst, 2005). Bu duruma, Alanya'daki deneyim örnek gösterilebilir (Tamer Görer vd., 2006). Ekonomik açıdan olumsuz etkilerin ikincisi, özellikle yabancıların ikinci konut talebinde etkili olan önemli doğal değerlerin olduğu bölgelerde konut fiyatlarında meydana gelen artışlardır (Hall ve Müller, 2004). Üçüncüsü ise, konut sahibi yabancıların kendi konutlarını kullanmaları neticesinde turizm gelirlerinin azalmasıdır. Türkiye'de yabancıların ikinci konut edinimi konusunda yapılan çalışmalarda, Dalyan, Alanya ve Didim yerleşmelerinde konut fiyatlarının yükselmesi ve bu durumun dolaylı etkisi olarak yerlilerin konut piyasasından dışlanması ekonomik açıdan olumsuz etki olarak tespit edilmiştir. Ayrıca Dalyan, Didim ve Kalkan'da turizm gelirlerinin azalması da ortaya çıkmıştır. Kalkan örneğinde inşaat sektöründe yabancı firmaların egemen olduğu da deneyimlenmiştir (Bakırc1, 2007; Karakaya ve Turan, 2006;Keskinok, Şahin Güçhan ve Özgönül 2005; Nudral1, 2007; Tamer Görer vd., 2006).

Gelişmekte olan ülkelerde özellikle, ikinci konutların ekonomik açıdan olumlu etkileri, kentlerin gelişimine yön veren plancılar ve politikacılar tarafindan merkeze alınmakta ve kentlere bu bağlamda yaklaşılmaktadır (Green, Marcouiller, Deller, Erkkila ve Sumathi, 1996). Bu nedenle yabanciların ikinci konut talebinin ve arzının yoğunlaştığı Dalyan, Alanya ve Didim yerleşmelerinde doğal alanlarda ve tarım alanlarında yapılaşma baskının arttığı ve buraların yapılaşmaya açıldığı görülmektedir (Avc1 vd., 2006; Bakırc1, 2007; Karakaya ve Turan, 2006; Nudral, 2007; Tamer Görer vd., 2006).

Yabancıların ikinci konut ediniminin gidilen kentteki sosyal yapıya etkisi, bütünleştirici ve ayrıştırıcı olmak üzere iki şekilde gerçekleşmektedir. Yabancıların ve yerel halkın uyum sağlaması ile oluşan, sosyal ilişkilerde bulunabildikleri, ortak yaşam ve aktivite alanlarının olduğu ve farklı etnik grupları içine almaya eğilimli bir sosyal yapı oluşturan bütünleştirici etkidir. Ayrıştırıcı etki ise, yabancıların hem sosyal ilişkiler hem de yaşam alanları bağlamında yerel halktan soyutlanarak kendi sosyal hayatlarını ve yaşam alanlarını oluşturmaları ile karşımıza çıkan durumdur (Casado-Diaz, 2008; Parker ve Song, 2006). Türkiye'de özellikle Alanya'da gündelik hayatta yerel halk ile yabancılar arasında sosyal kutuplaşmanın olduğu ve ayrıştırıcı etki gözlenmektedir. Bunun en önemli sebebi olarak yerel halk ile yabancıların farklı dilleri konuşmalarının yarattığı iletişim problemleridir (Tamer Görer vd., 2006). Benzer şekilde, Trabzon'da bu konuda yapılan bir çalışmada, yerel halkın Araplar ile aynı konut alanında yaşamak istemedikleri ve bunlar arasında ayrışmacı bir tutum gözlemlenmektedir Arapların kalabalık aile yapısı, sosyokültürel farklıkları ve genellikle konutlarını yazın tatil amaç lı kullanmaları yerel halk tarafindan eleştirilmektedir (Yılmaz Bayram ve Bayram, 2016).

\section{AMAÇ VE YÖNTEM}

Yabancıların ikinci konut talebinin ve ediniminin kentlerin sosyal ve ekonomik yapısına olumlu ya da olumsuz etkileri bulunmaktadır. Türkiye'de 2012 yılı öncesinde konut edinen yabancılara ilişkin bu etkileri ortaya koyan çalışmalar mevcuttur. Ancak karşılıklılık ilkesinin kaldırılması ile birlikte konut edinen yabancıların uyruklarının ve tercih edilen kentlerin değişimiyle birlikte deneyimlenen sürece ilişkin çalışmalar kısıtlıdır. Bu nedenle, çalışmada ülkemizde 2012 yılı sonrasında yabancıların ikinci konut ediniminin, kentlerin sosyal ve ekonomik yapısına etkilerini belirlemek amaçlanmıştır. Yapılan alan yazısı taraması ve ampirik çalışmalardan elde edilen bulgular çerçevesinde şu sorulara yanıt aranmaktadır: 1. 2012 y1lı sonrasında Trabzon'da ikinci konut edinmeye başlayan yabancıların sosyal ve demografik yapıları nasıldır? 2. 2012 yılı sonrasında Trabzon'da ikinci konut edinmeye başlayan yabancıların konut taleplerinin nedenleri ve özellikleri nelerdir? 3.Trabzon'dan ikinci konut edinen yabanciların kentin sosyal ve ekonomik yapısına etkileri nelerdir?

$\mathrm{Bu}$ çalışmada dil konusundaki kısıtlılıklar yönteminin belirlenmesinde etkili olmuştur. Trabzon'da konut edinen yabancıların Arap ülkeleri vatandaşları olmasından ötürü Arapçayı ana dil olarak kullanmaları, araştırmacıların ise Türkçe'yi ve İngilizce'yi etkin kullanımından ötürü ortak bir iletişim dili bulunamamıştır. Bu nedenle çalışmada nitel bir araştırma yöntemi olan anket uygulaması seçilmiştir. Trabzon'da ikinci konut edinen yabancilar ve kentte konut arzinı 
gerçekleştiren inşaat firmalarındaki yetkililer ile olmak üzere iki anket çalışması yapılmıştır. İlde ikinci konut edinen yabancılara yönelik Türkçe hazırlanan anket formu Arapça'ya çevrilerek deneklere uygulanmıştır. Arapların konut taleplerini belirlemeye yönelik anket çalışmasında denek sayısı belirlenirken, Trabzon'da ikinci konut edinen yabancı sayısına ulaşılamadığ için, kentte bağımsız bölüm sahibi yabancıların sayısı üzerinden hesaplama yapılmıştır. Tapu Kadastro Genel Müdürlüğü (2017)'ne kayıtlı kentte bağımsız bölüm sahibi olan yabancı sayısı (evren büyüklüğü) 1762 'dir. $\% 95$ güven düzeyi ve $\pm \% 10$ örnekleme hata payı ile örneklem ikinci konut sahibi yabancılar $\mathrm{n}=60$ kişi olarak belirlenmiştir. Anket katılımcıları basit tesadüfî örnekleme yöntemiyle seçilmiştir ve yüz yüze uygulanmıştır.

Kentte konut arzını gerçekleştiren inşaat firmaları ile de yüz yüze anket yapılmıştır. Bu anketin denekleri belirlenirken, grup örnekleme yöntemi kullanılmıştır. Yabancılarla yapılan anket çalışmasının sonuçlarına göre, onların kentte genellikle site tipi konut satın aldıkları, bunları da çoğunlukla inşaat firmalarından ve internetten görüp beğenerek edindikleri tespit edilmiştir. $\mathrm{Bu}$ doğrultuda internet üzerinden konut projesinin tanıtımı yapılan firmaları ve bunların ürettikleri proje sayıları belirlenmiştir ve buna göre Trabzon'daki konut projelerinin \%75'i sadece 6 firma ve $\% 25$ 'de 31 firma tarafından üretildiği tespit edilmiştir. Çalışma kapsamında \% $75^{\prime}$ lik konut arzını gerçekleştiren altı ve $\% 25$ 'lik kesim içerisinden ise sekiz olmak üzere toplam 14 inşaat firması ile anket çalışması yapılmıştır. Bazı inşaat firmalarının anket çalışmasına katılmaması ve bazılarına da ulaşılamadığı için örneklem sayısı 14'le sınırlı kalmıştır.

Konut sahibi yabancılara yapılan ankette, onların sosyal ve demografik yapıları, ana vatanları, Trabzon'da konut edinme nedenleri, kentte ilişkin deneyimleri, ikinci konut tercihlerinin nedenleri ve konutların özellikleri araştırma ile belirlenmek istenmiştir. İnşaat firmalarına yapılan anketle de, yerli ve yabancı müşterilerin konut talepleri arasındaki farkl1l1klar ve bunların kent coğrafyasındaki dağılımları ve kentteki sosyal ve ekonomik etkileri tespit edilmek istenmiştir. İki anket formunda çoktan seçmeli, açık ve kapalı uçlu sorular bulunmaktadır. Elde edilen veriler SPSS programında tanımlayıcı istatistiksel analizlerle değerlendirilmiştir.

\section{ARASTTIRMA ALANI}

Türkiye'de Karadeniz Bölgesi'nin Doğu Karadeniz kesiminde yer alan Trabzon, 2012 yllında büyükşehir belediyesi statüsüne kavuşmuştur. Trabzon kara, deniz ve hava yolu ulaşım bağlantıları güçlü, Karadeniz Sahil Yolu'na paralel doğu-batı yönünde lineer gelişim gösteren bir yerleşmedir.

Çalışma alanı olarak Trabzon'un seçilmesinde ise iki önemli neden vardır. Bunlardan ilki, Trabzon'un, Türkiye'de 2014 yılı itibariyle yabancıların ikinci konut ediniminde ilk on şehir arasına girmiş olmasıdır (Şekil 1). 2014 yılından önce ülkemizde genellikle Ege, Akdeniz ve Marmara Bölgeleri'nde yabancıların bağımsız bölüm edindikleri görülmektedir. Trabzon, 2014-2017 yılları arasında Karadeniz Bölgesi'nde, 2018 ve 2019 yıllarında ise Doğu Karadeniz'de, ülkemizde yabancıların konut edindiği ilk on il sıralamasına girmiş tek ildir (Tablo 1). İkinci neden ise, ilde en fazla bağımsız bölüm edinen yabancıların, ülkemizde 2012 yılı sonrasında karşılıklılık ilkesi kaldırıldıktan sonra mülk edinme hakkı kazanan Arap Ülkeleri vatandaşlarının olmasıdır.

Trabzon ilinde bağımsız bölüm satın alan yabancıların uyruklarına ilişkin veriler incelendiğinde, 1463 bağımsız bölüm

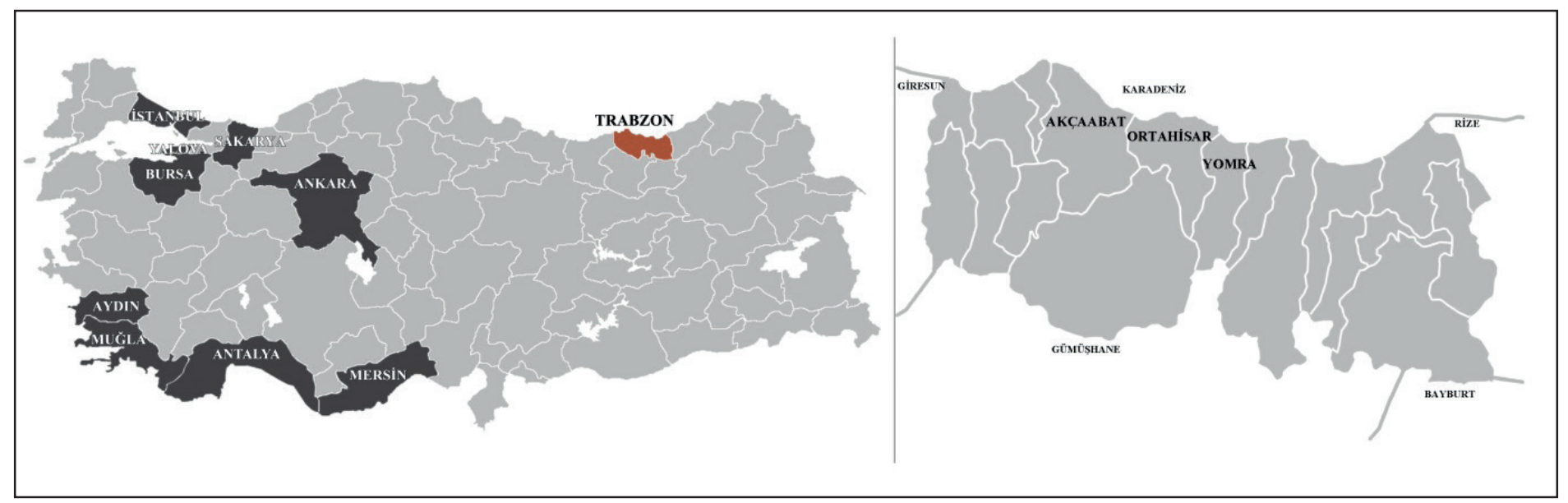

Şekil 1: Türkiye'de 2014 -2017 yılları arasında yabancıların konut edindiği ilk on il ve Trabzon'un konumu (TÜiK, 2021).

Figure 1: Top ten provinces in Turkey where foreigners bought housing between 2014 and 2017 and location of Trabzon (TÜIK, 2021). 
Tablo 1. İllere göre yabancılara yapılan konut satış sayıları, 2014-2019 (TUIK, 2021).

Table 1. Number of housing sales to foreigners by provinces, 2014-2019 (TUIK, 2021).

\begin{tabular}{|c|c|c|c|c|c|c|c|c|c|c|c|}
\hline \multicolumn{2}{|c|}{2014} & \multicolumn{2}{|c|}{2015} & \multicolumn{2}{|c|}{2016} & \multicolumn{2}{|c|}{2017} & \multicolumn{2}{|c|}{2018} & \multicolumn{2}{|c|}{2019} \\
\hline Antalya & 6542 & İstanbul & 7493 & İstanbul & 5811 & İstanbul & 8182 & İstanbul & 14270 & İstanbul & 20857 \\
\hline İstanbul & 5580 & Antalya & 6072 & Antalya & 4352 & Antalya & 4707 & Antalya & 7938 & Antalya & 8951 \\
\hline Aydın & 1191 & Bursa & 1501 & Bursa & 1318 & Bursa & 1474 & Bursa & 2720 & Ankara & 2539 \\
\hline Muğla & 1051 & Yalova & 1425 & Aydın & 871 & Yalova & 1079 & Ankara & 2133 & Bursa & 2213 \\
\hline Bursa & 954 & Aydın & 1107 & Yalova & 822 & Trabzon & 978 & Yalova & 2063 & Yalova & 1696 \\
\hline Mersin & 783 & Sakarya & 833 & Trabzon & 810 & Aydın & 826 & Sakarya & 1366 & Sakarya & 1247 \\
\hline Yalova & 765 & Muğla & 830 & Sakarya & 657 & Ankara & 817 & Trabzon & 1344 & Muğla & 957 \\
\hline Sakarya & 512 & Trabzon & 778 & Muğla & 632 & Sakarya & 770 & Aydın & 1070 & Trabzon & 935 \\
\hline Ankara & 369 & Mersin & 717 & Ankara & 623 & Muğla & 634 & Mersin & 1022 & Samsun & 885 \\
\hline Trabzon & 225 & Ankara & 599 & Mersin & 580 & Mersin & 600 & Samsun & 956 & Aydın & 837 \\
\hline Diğer iller & 987 & Diğer iller & 1475 & Diğer iller & 1713 & Diğer iller & 2167 & Diğer iller & 4781 & Diğer iller & 4366 \\
\hline Toplam & 18959 & Toplam & 22830 & Toplam & 18189 & Toplam & 22234 & Toplam & 39663 & Toplam & 45483 \\
\hline
\end{tabular}

sayısı ile (\%65) Suudi Arabistan ilk sirada yer almaktadır. Bunu 424 bağımsız bölüm sayısı (\%19) ile Kuveyt takip etmektedir. İlde bağımsız bölüm satın alan Araplar içerisinde, \%2'lik oranlarıyla Katar, Ürdün ve Birleşik Arap Emirlikleri vatandaşları ve \%1'lik oranıyla da Irak, Yemen, Filistin ve Mısır vatandaşları bulunmaktadır. Trabzon'da bağımsız bölüm satın alan diğer ülkelerin vatandaşlarının oranı sadece \%6'dır (TKGM, 2017 Haziran).

\section{BULGULAR}

Yabancıların ikinci konut talebini etkileyen etmenlerin belirlenmesine yönelik anket çalışmasına katılan deneklerin \%77'si Suudi Arabistan, \%10'i Kuveyt ve \%13'ü ise diğer ülkelerin (Afganistan, Bahreyn, Filistin ve Katar) vatandaşlarıdır ve tamamı erkektir. Araplar, 28 ile 65 yaş arasındadır ve yaşlarının ortalaması 48 'dir. Deneklerin yaklaşık üçte ikilik kısmı üniversite ve üstü eğitim düzeyine sahiptir. Yabancıların \%38'lik kesimi emekli, memur, emlakçı, esnaf, inşaat çalışanı, iş adamı, öğretim görevlisi ve serbest meslek mensubudur (Tablo 2). Arapların gelir dağılımları incelendiğinde, aylık ortalama gelirleri16000TL-25000 TL aralığında olan denek oranı \%50'dir. Katılımcıların \%86,7'si evli ve çocuk sahibidir. Üç çocuklu aileler \%31 oranıyla çoğunluktadır. Ankete katılan Arapların en az bir, en fazla sekiz çocuğu vardır ve ortalama hanehalkı büyüklüğü 4,6'dır.Deneklerin çocuklarının yaşlarına ilişkin soruya verdikleri yanıtlar, Türkiye'deki örgün eğitime katılan çocukların yaşlarıyla karşılaştırıldığında, bu ailelerin çocuklarının \%19'u ilköğretim, \%14'ü lise ve \%22'si ise üniversite çağında olduğu görülmektedir (Tablo 2).

\section{1. İkinci konut talebinin nedenleri ve özellikleri}

Ankete katılan Arapların \%87'sinin kendi ülkesi dışında sadece Türkiye'de ve \%70'inin yalnızca Trabzon'da ikinci konutu bulunmaktadır. Deneklerin \%84'ü geçmişte başkalarına Trabzon'dan konut satın almalarını tavsiye etmiş ve benzer şekilde \%87'lik kesimi ise gelecekte başkalarına buradan konut alınmasını tavsiye edebileceklerini belirtmişlerdir. "Trabzon'a yerleşip, burada yaşamak ister misiniz" sorusuna, deneklerin \%43'ü evet cevabını vermiştir. Bunun nedenlerine ilişkin soru açık uçlu olarak yöneltilmiş ve birden fazla cevap verme hakk1 tanınmıştır. Yanıtlar, doğal güzellikler (\%41), güzel şehir olması (\%23), sakin şehir olması (\%12), güvenlik (\%6), rahat bir şehir (\%6), halkın olumlu tutumu (\%6) ve tatil (\%6) olmak üzere yedi grupta toplanmıştır. Yabancıların kente yerleşmek isteme nedenleri arasında, Trabzon'un fiziksel özelliklerinin, sosyal özelliklerinden daha etkili olduğu tespit edilmiştir.

Ankete katılan konut sahibi yabancıların tamamı konut satın almadan önce kentte en az bir kez bulunmuştur (Tablo 3). “Trabzon'a daha önce geliş amacinız nedir?" sorusunun yanıtları değerlendirildiğinde katılımcıların tamamına yakını (\%87) turistik ziyaret, yaklaşık beşte birlik bölümü de iş amaçlı kentte geldiği belirlenmiştir. Arapların üçte ikisi sadece yaz mevsiminde Trabzon'da kalırken, yılın diğer mevsimleri kentte kalan yabancı oranı oldukça düşüktür (Tablo 3). Kenti tercih etme nedenlerini belirlemeye yönelik soruya verilen cevaplar değerlendirildiğinde, katılımcıların üçte ikisinin daha önce kente gelip beğenmiş olduklarını görmekteyiz. Bunu internette kenti görüp beğenenler, tanıdık ve akraba tavsiyesi ile kenti tercih edenler takip etmektedir (Tablo 3).

Yabancıların farklı ülkede ikinci konut edinmelerinde etkili öğelerin, Arapların Trabzon'da ikinci konut edinmesine etki düzeyleri tespit edilmeye çalışılmıştır. Bunun için önceden belirlenen 14 öğenin etkilerini likert ölçeğinde olumsuz etkili (1) ile olumlu etkili (5) arasında derecelendirmeleri istenmiş̧tir. Araplar tarafından olumlu etkileyen öğeler içerisinde \%77'lik oranla Trabzon'un güvenli bir kent oluşu ilk sırada yer almaktadır. 
Tablo 2: Arapların sosyal ve demografik özellikleri.

Table 2: Social and demographic characteristics of Arabs.

\begin{tabular}{|c|c|c|c|}
\hline \multicolumn{2}{|l|}{ Değişken } & \multirow{2}{*}{$\begin{array}{c}\mathbf{N} \\
8\end{array}$} & \multirow{2}{*}{$\begin{array}{c}\text { (\%) } \\
13\end{array}$} \\
\hline Yaş & $28-35$ & & \\
\hline & $36-45$ & 14 & 23 \\
\hline & $46-55$ & 22 & 37 \\
\hline & $56-65$ & 16 & 27 \\
\hline \multirow[t]{3}{*}{ Uyruk } & Suudi Arabistan & 46 & 77 \\
\hline & Kuveyt & 6 & 10 \\
\hline & Diğer (Afganistan, Bahreyn, Filistin ve Katar) & 8 & 13 \\
\hline \multirow[t]{2}{*}{ Medeni durum } & Evli & 52 & 87 \\
\hline & Bekar & 8 & 13 \\
\hline \multirow[t]{2}{*}{ Çocuklar sahipliği } & Var & 52 & 87 \\
\hline & Yok & 8 & 13 \\
\hline \multirow[t]{5}{*}{ Çocukların yaş aralığı } & $0-6$ & 5 & 9 \\
\hline & 7-14 İlköğretim Çağı & 10 & 19 \\
\hline & 15-18 Lise Çağı & 7 & 14 \\
\hline & 19-24 Üniversite Çağı & 11 & 22 \\
\hline & 25 ve üzeri Çalışma Çağı & 19 & 36 \\
\hline \multirow[t]{5}{*}{ Eğitim durumları* } & Eğitimsiz & 2 & 3,5 \\
\hline & İlköğretim & 2 & 3,5 \\
\hline & Lise & 12 & 21 \\
\hline & Üniversite & 34 & 61 \\
\hline & Üniversite ve üzeri & 6 & 11 \\
\hline \multirow[t]{5}{*}{ Meslek ${ }^{* *}$} & Mühendis & 12 & 21 \\
\hline & Öğretmen & 10 & 17 \\
\hline & Doktor & 8 & 14 \\
\hline & Tüccar & 6 & 10 \\
\hline & Diğer (emekli, memur, emlakçı, esnaf, inşaat çalışanı, iş adamı, öğretim görevlisi ve serbest meslek) & 22 & 38 \\
\hline \multirow[t]{3}{*}{ Gelir dağılımı } & $8000-15000 \mathrm{TL}$ & 22 & 37 \\
\hline & $16000-25000 \mathrm{TL}$ & 30 & 50 \\
\hline & $26000-55000 \mathrm{TL}$ & 8 & 13 \\
\hline
\end{tabular}

*Dört kişi soruya yanıt vermemiştir. **iki kişi soruya yanıt vermemiştir.

*Four participants did not answer the question **Two participants did not answer the question

Tablo 3: Arapların Trabzon ile ilgili deneyimleri.

Table 3: The experience of the Arabs with the city of Trabzon.

\begin{tabular}{|c|c|c|c|}
\hline Değişken & & $\mathbf{N}$ & (\%) \\
\hline \multirow[t]{3}{*}{ Daha önce bulunma durumu } & 1 defa & 32 & 53 \\
\hline & $2-5$ sefer & 22 & 37 \\
\hline & 6 sefer ve üzeri & 6 & 10 \\
\hline Ziyaret amacı & Turistik & 52 & 87 \\
\hline \multirow[t]{2}{*}{ (birden fazla cevaplanabilir) } & İş & 10 & 17 \\
\hline & Tanıdık ve akraba ziyareti & 8 & 13 \\
\hline \multirow[t]{5}{*}{ Kalış süresi } & $0-15$ gün & 16 & 27 \\
\hline & 1 ay & 20 & 33 \\
\hline & 2-3 ay & 22 & 37 \\
\hline & 4-6 ay & 0 & 0 \\
\hline & 7 ay ve üzeri & 2 & 3 \\
\hline \multirow{7}{*}{$\begin{array}{l}\text { Kalış mevsimi } \\
\text { (birden fazla cevaplanabilir) }\end{array}$} & Yaz & 44 & 74 \\
\hline & Kış & 2 & 3 \\
\hline & İlkbahar & 4 & 7 \\
\hline & Sonbahar & 4 & 7 \\
\hline & Yaz-Kış-Ilkbahar & 2 & 3 \\
\hline & Yaz-Illkbahar-Sonbahar & 2 & 3 \\
\hline & Yaz-Kış-İlkbahar- Sonbahar & 2 & 3 \\
\hline \multirow{3}{*}{$\begin{array}{l}\text { Kenti tercih etme nedeni } \\
\text { (birden fazla cevaplanabilir) }\end{array}$} & Tanıdık ve akraba tavsiyesi & 16 & 27 \\
\hline & Daha önce gelip beğenilmiş olunması & 42 & 70 \\
\hline & İnternette görüp beğenilmiș olunması & 22 & 37 \\
\hline
\end{tabular}


Bunu iklim (\%70), doğal ve tarihi güzellikler (\%67), dini inanışların benzerliği (\%63) ve Türk kültürü (\%50) izlemektedir. Kısmen olumlu etkileyen etmenler içerisinde \%43 oranıyla kent halkının tutumu öne çıkmaktadır. Katılımcılar tarafından, tanıdıkların ve akrabaların aynı şehirden konut edinmesi, iş ve ticari ilişkiler, emlak piyasasının durumu ve konut edinimindeki resmi süreçler yüksek oranda etkisiz etmenler olarak değerlendirilmiştir (Tablo 4). Özetle, Arapların Trabzon'da ikinci konut edinmelerinde kentin fiziksel ve sosyal özelliklerinin, diğer özelliklerine kıyasla yüksek oranlarda olumlu ve kısmen olumlu etkili öğeler olduğu tespit edilmiştir.

Arapların Trabzon'daki hizmetleri ve olanakları değerlendirmeleri için önceden belirlenen 16 öğenin yeterliliklerini likert ölçeğinde, yetersiz (1) ile yeterli (5) arasında derecelendirmeleri istenmiştir. Deneklerin, \%80’i yeşil alanları ve \%77'si de doğal çevrenin güzelliklerini yeterli bulmuştur. Kentteki günübirlik turizm alanları ve yerel halkın tutumu da yeterli görülen konular arasında öne çıkmaktadır. Trabzon'daki eğitim olanakları, yurtiçi, yurtdışı ve kent içi ulaşım imkânları ile yaşam maliyeti denekler tarafından kısmen yeterli olarak değerlendirilmiştir. Kısmen yetersiz ve yetersiz olarak değerlendirilen hizmetlerin ve olanakların oranı düşük düzeydedir (Tablo 5). Kisaca, denekler tarafindan kentin hizmetleri ve olanakları genel olarak orta ve üzeri seviyede yeterli bulunmaktadir.

Araplar'ın Trabzon'da konut edindikleri yerleri belirlenmeye yönelik sorunun cevapları incelendiğinde, kentin doğusundaki mahallelerin batısındaki mahallelere oranla daha fazla tercih

Tablo 4: Arapların Trabzon'da ikinci konut edinmelerinde etkili öğeler.

Table 4: Effective factors for Arabs in bought a second home in Trabzon.

\begin{tabular}{|c|c|c|c|c|c|c|}
\hline & $\begin{array}{c}\text { Olumlu Etkili } \\
(\%)\end{array}$ & $\begin{array}{l}\text { Kısmen Olumlu } \\
\text { Etkili (\%) }\end{array}$ & $\begin{array}{c}\text { Etkisiz } \\
(\%)\end{array}$ & $\begin{array}{c}\text { Kısmen Olumsuz } \\
\text { Etkili (\%) }\end{array}$ & $\begin{array}{c}\text { Olumsuz Etkili } \\
(\%)\end{array}$ & $\begin{array}{c}\text { Yanıt Yok } \\
(\%)\end{array}$ \\
\hline Tanıdık ve akrabaya yakınlık & 10 & 10 & 47 & 0 & 0 & 33 \\
\hline Kent halkının tutumu & 23 & 43 & 17 & 0 & 0 & 17 \\
\hline Türk kültürü & 50 & 37 & 10 & 0 & 0 & 3 \\
\hline Dini inanışların benzerliği & 63 & 13 & 10 & 0 & 0 & 13 \\
\hline Sakin yaşam koşulları & 33 & 33 & 17 & 0 & 0 & 17 \\
\hline Hareketli yaşam koşulları & 7 & 13 & 43 & 3 & 3 & 30 \\
\hline Güvenli bir kent olması & 77 & 13 & 0 & 0 & 0 & 10 \\
\hline Yaşam maliyeti & 37 & 23 & 20 & 0 & 0 & 20 \\
\hline Emlak piyasasının durumu & 3 & 20 & 30 & 17 & 0 & 30 \\
\hline İş ve ticari ilişkiler & 13 & 20 & 43 & 0 & 0 & 23 \\
\hline Resmi süreçler & 13 & 20 & 30 & 7 & 3 & 27 \\
\hline Tarihi ve doğal güzellikler & 67 & 27 & 0 & 3 & 0 & 3 \\
\hline İklim & 70 & 23 & 0 & 3 & 0 & 3 \\
\hline Kentin ulaşım imkânları & 23 & 33 & 17 & 3 & 0 & 23 \\
\hline
\end{tabular}

Tablo 5: Arapların Trabzon'daki hizmetleri ve olanakları değerlendirmesi. Table 5: Arabs' view on services and facilities in Trabzon.

\begin{tabular}{|c|c|c|c|c|c|c|}
\hline & $\begin{array}{c}\text { Yeterli } \\
\text { (\%) }\end{array}$ & $\begin{array}{c}\text { Kısmen Yeterli } \\
\text { (\%) }\end{array}$ & $\begin{array}{c}\text { Etkisiz } \\
(\%)\end{array}$ & $\begin{array}{c}\text { Kısmen Yetersiz } \\
\text { (\%) }\end{array}$ & $\begin{array}{c}\text { Yetersiz } \\
(\%)\end{array}$ & $\begin{array}{c}\text { Yanit Yok } \\
(\%)\end{array}$ \\
\hline Ticari hizmetler & 17 & 40 & 33 & 0 & 0 & 10 \\
\hline Sağlık hizmetleri & 37 & 40 & 7 & 3 & 0 & 13 \\
\hline Sosyal faaliyetler & 20 & 20 & 53 & 0 & 0 & 7 \\
\hline Eğitim olanakları & 7 & 57 & 20 & 3 & 0 & 13 \\
\hline Günübirlik turizm alanları & 43 & 27 & 17 & 3 & 3 & 7 \\
\hline Turizm konaklama tesisleri & 33 & 37 & 17 & 3 & 0 & 10 \\
\hline Eğlence dinlence alanları & 47 & 13 & 27 & 3 & 3 & 7 \\
\hline Yeşil alanlar & 80 & 13 & 3 & 0 & 0 & 3 \\
\hline Altyapı & 10 & 37 & 33 & 10 & 0 & 10 \\
\hline Kent içi ulaşım imkânları & 20 & 43 & 27 & 0 & 0 & 10 \\
\hline Yurtiçi ulaşım imkânları & 17 & 53 & 17 & 0 & 0 & 13 \\
\hline Yurtdışı ulaşım imkânları & 10 & 40 & 23 & 3 & 0 & 23 \\
\hline Doğal çevrenin güzelliği & 77 & 2 & 0 & 0 & 0 & 0 \\
\hline Yerel halkın tutumu & 37 & 27 & 30 & 3 & 0 & 3 \\
\hline Yerel esnafın tutumu & 23 & 33 & 30 & 7 & 0 & 7 \\
\hline Yaşam maliyeti & 27 & 47 & 10 & 13 & 0 & 3 \\
\hline
\end{tabular}


edildiği tespit edilmiştir (Şekil 2). Yabancıların en fazla konut edindiği Kaşüstü Mahallesi’ni (\%50), Pelitli (\%13) ve Yalıncak (\%10) Mahalleri izlemektedir. Onların en az konut satın aldıkları yer ise kentin batısındaki Söğütlü Mahallesi’dir (\%3). Yabancıların sahip oldukları konutların özelliklerini belirlemeye yönelik soruya verilen yanıtlar incelendiğinde, \%67'sinin site içerisinde konutlarının bulunduğu ve yalnızca \%7'sinin müstakil evi olduğu tespit edilmiştir. Onların sahip oldukları konutların büyüklüğü $120 \mathrm{~m}^{2}$ ile $210 \mathrm{~m}^{2}$ arasında değişmektedir. Sahip olunan konutların ortalama büyüklüğü ise yaklaşı1k $171 \mathrm{~m}^{2}$ 'dir. Araplar üç, dört ve beş odalı konutlar satın almaktadır, ancak \%20'si beş odalı konut talep etmektedir (Tablo 6). Bu bulgular yabancıların sahip oldukları konutlardan hem daha büyük hem de daha fazla odası bulunan konut talep ettiklerini göstermektedir.

\section{2. İkinci konutların kente sosyal ve ekonomik etkileri}

$\mathrm{Bu}$ bölümde, ikinci konutların yerelde konut fiyatlarına, turizm gelirlerine ve istihdam alanı oluşturmaya etkileri, sosyal bütünleşme veya ayrışma bağlamında yerel halk ile yabancıların yaşam alanları arasındaki ilişkilere yönelik bulgular yer almaktadır.

İnşaat firmaları ile yapılan ankette, yerli ve yabancı müşterilerin konut satın almak için ilk sırada tercih ettikleri mahalle sorulmuştur. Katılımcılar Arapların genellikle Kaşüstü Mahallesi’ni (\%66), Trabzonluların ise Boztepe (\%29) ve Beşirli (\%29) Mahallelerini tercih etmektedir. Yerli ve yabancı müşterilerin mahalle düzeyinde tercihleri farklılaşmaktadır. Yabancıların, Trabzon'un doğusunda 2000'li yıllardan sonra gelişen ve kentin ikinci alt merkezi olarak nitelendirilecek alanlarda yaşamak istedikleri, yerlilerin ise kentin batı ve güney tarafını tercih ettikleri görülmektedir.

Ankete katılan firmalardan yerli ve yabancı müşterilerin konut tercihlerinde önceden belirlenen 16 öğenin etkilerini likert ölçeğinde, olumsuz etkili (1) ile olumlu etkili (5) arasında derecelendirmeleri istenmiştir. Bu soruya verilen yanıtlara göre; fiyat, güvelik, büyüklük ve manzara iki kesim için de olumlu etkili olarak nitelendirilmektedir. Merkeze yakınlık, sosyal ve

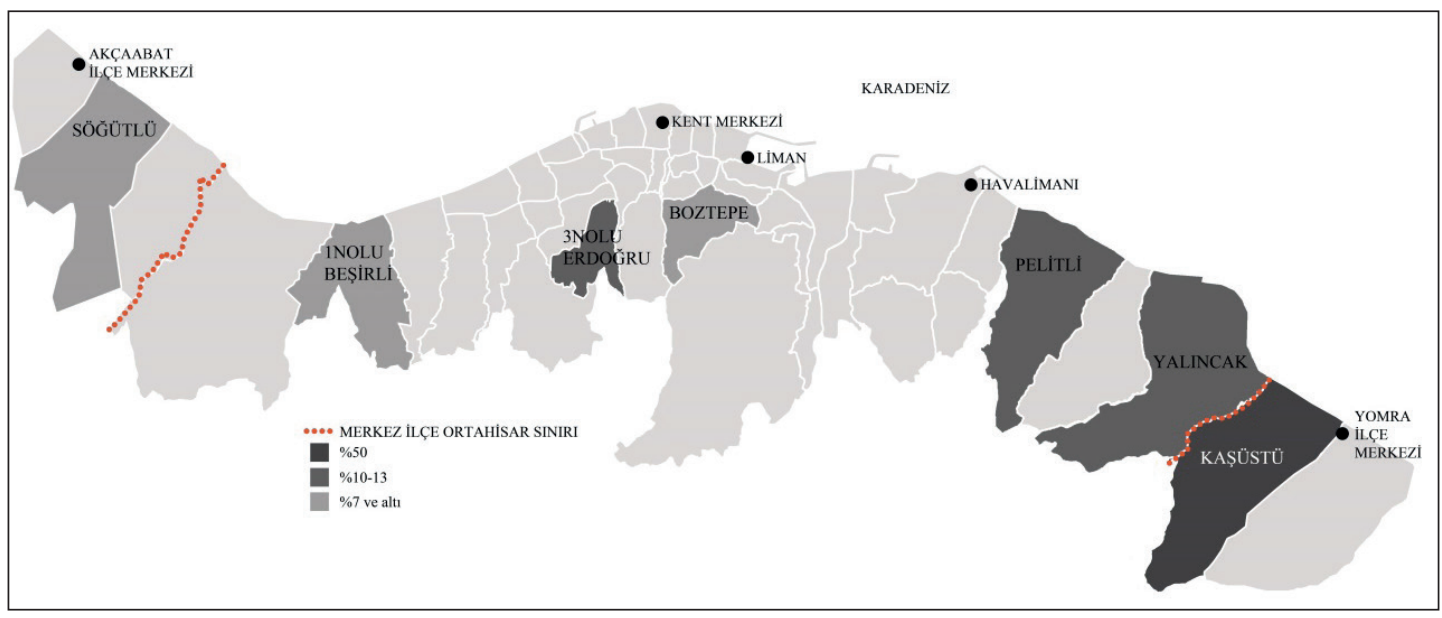

Şekil 2: Arapların Trabzon'da konut edindikleri mahallelerin yüzdelik dağılımları ve konumları. Figure 2: Percentage of neighborhoods where Arabs bought second home in Trabzon, and their locations.

Tablo 6: Arapların sahip oldukları ve talep ettikleri ikinci konutların özellikleri. Table 6: Features of second homes owned and demanded by Arabs.

\begin{tabular}{|c|c|c|c|c|c|}
\hline \multirow{2}{*}{ Değişken } & & \multicolumn{2}{|c|}{ Sahip olunan konut } & \multicolumn{2}{|c|}{ Talep edilen konut } \\
\hline & & $\mathbf{N}$ & (\%) & $\mathbf{N}$ & (\%) \\
\hline \multirow[t]{3}{*}{ Büyüklük } & $120-179 m^{2}$ & 28 & 47 & 18 & 30 \\
\hline & $180-210 m^{2}$ & 32 & 53 & 20 & 33 \\
\hline & Yanit yok & - & - & 22 & 37 \\
\hline \multirow[t]{6}{*}{ Oda sayısı } & 2 & 4 & 7 & 2 & 3 \\
\hline & 3 & 20 & 33 & 10 & 17 \\
\hline & 4 & 18 & 30 & 8 & 13 \\
\hline & 5 & 18 & 30 & 12 & 20 \\
\hline & 6 & - & - & 2 & 3 \\
\hline & Yanıt yok & - & - & 26 & 44 \\
\hline
\end{tabular}


kültürel alanlar, doğaya yakınlık ve ticari faaliyetler yerliler için kısmen olumlu yabancılar için olumlu olmak üzere iki grup için de pozitif etkili öğeler olarak tespit edilmiştir. Denize yakınlık, havalimanına yakınlık, akraba ve tanıdıkların oluşu, yerli halkın oluşu ve doğaya yakınlık yerliler için etkilemeyen öğeler olurken, yabancılar için olumlu etkili öğeler olarak belirtilmiştir (Tablo 7). Yerli ve yabancı müşterilerin konut tercihinde "diğer yabancıların varlı̆̆ı”, iki grubu farklı şekilde etkileyen tek öğedir. Bu öğe, Trabzonluların taleplerini olumsuz etkilerken, Araplar tarafindan diğer yabancılar ile (Türkler, vb.) ile aynı konut alanı içerisinde bulunmak olumlu etkili öğe olarak değerlendirilmiştir.

Firmalar ile yapılan ankette Arap müşterilerin \%83'ü konutlarını bittikten sonra, yerli müşterilerin \%79'u ise evlerini proje aşamasında satın aldıkları tespit edilmiştir. Firma yetkililerine bunun nedenleri açık uçlu soru olarak yöneltilmiştir. Katılımcılar, genellikle yerli müşterilerin alım gücünün bitmiş konut fiyatlarının altında olması sebebiyle evlerini proje aşamasında, topraktan satın almayı tercih ettiklerini belirtmişlerdir. Firmaların tamamı, Arapların bitmiş konut satın alma sebebi olarak projelerin taahhüt edilen tarihte bitirilememesini göstermiştir. Bu bulgular mekânsal ayrıştırıcı etkiye rağmen yerlilerin topraktan aldığı projelere yabancıların bittikten sonra dahil olması ile yerli ve yabancıların aynı konut projesinde bir arada bulunma ihtimalini doğurabilir.

Yabancılar ile yapılan anket çalışmasında, satın aldıkları konutların fiyatı sorulduğunda yarıdan fazlası 300000TL -499999 TL aralığında ücret ödediğini belirtmiştir (Tablo 8). İnşaat firmasındaki yetkililer, Arap müşterilerin \%93'ü

Tablo 7: Yerli ve yabancı müşterilerin konut tercihlerini etkileyen öğelerin değerlendirilmesi

Table 7: Evaluation of factors affecting the housing preferences of domestic and foreign customers.

\begin{tabular}{|c|c|c|c|c|c|c|c|c|c|c|}
\hline & \multicolumn{2}{|c|}{$\begin{array}{l}\text { Olumlu Etkili } \\
\text { (\%) }\end{array}$} & \multicolumn{2}{|c|}{$\begin{array}{l}\text { Kısmen Olumlu Etkili } \\
(\%)\end{array}$} & \multicolumn{2}{|c|}{$\begin{array}{c}\text { Etkisiz } \\
(\%)\end{array}$} & \multicolumn{2}{|c|}{$\begin{array}{l}\text { Kısmen Olumsuz Etkili } \\
(\%)\end{array}$} & \multicolumn{2}{|c|}{$\begin{array}{l}\text { Olumsuz Etkili } \\
(\%)\end{array}$} \\
\hline & $\mathbf{Y}$ & YB & $\mathbf{Y}$ & YB & $\mathbf{Y}$ & YB & $\mathbf{Y}$ & YB & $\mathbf{Y}$ & YB \\
\hline Diğer yabancıların varlığı & 0 & 50 & 0 & 42 & 29 & 8 & 21 & 0 & 50 & 0 \\
\hline Trabzonluların varlığı & 29 & 50 & 21 & 42 & 50 & 8 & 0 & 0 & 0 & 0 \\
\hline Tanıdık ve akraba varlığı & 29 & 58 & 14 & 25 & 57 & 17 & 0 & 0 & 0 & 0 \\
\hline Fiyat & 100 & 100 & 0 & 0 & 0 & 0 & 0 & 0 & 0 & 0 \\
\hline Güvenlik & 93 & 92 & 7 & 8 & 0 & 0 & 0 & 0 & 0 & 0 \\
\hline Büyüklük & 86 & 92 & 14 & 8 & 0 & 0 & 0 & 0 & 0 & 0 \\
\hline Sosyal ve kültürel donatılar & 29 & 83 & 64 & 17 & 7 & 0 & 0 & 0 & 0 & 0 \\
\hline Ticari faaliyetler & 29 & 92 & 50 & 0 & 21 & 8 & 0 & 0 & 0 & 0 \\
\hline Sağlık donatıları & 7 & 0 & 79 & 8 & 14 & 92 & 0 & 0 & 0 & 0 \\
\hline Eğitim donatıları & 7 & 0 & 71 & 17 & 21 & 83 & 0 & 0 & 0 & 0 \\
\hline Havaalanına yakınlık & 7 & 92 & 0 & 0 & 93 & 8 & 0 & 0 & 0 & 0 \\
\hline Merkeze uzaklık & 28 & 0 & 0 & 8 & 21 & 17 & 50 & 58 & 0 & 17 \\
\hline Merkeze yakınlık & 43 & 58 & 50 & 25 & 7 & 8 & 0 & 0 & 0 & 8 \\
\hline Doğaya yakınlık & 28 & 100 & 36 & 0 & 36 & 0 & 0 & 0 & 0 & 0 \\
\hline Denize yakınlık & 28 & 75 & 28 & 17 & 43 & 8 & 0 & 0 & 0 & 0 \\
\hline Manzara & 43 & 100 & 36 & 0 & 21 & 0 & 0 & 0 & 0 & 0 \\
\hline
\end{tabular}

Y:Yerli Müşteri YB: Yabancı Müşteri

Y: Domestic Customer YB: Foreign Customer

Tablo 8: Arapların sahip oldukları ikinci konuta dair bilgiler.

Table 8: Information about the second homes owned by the Arabs.

\begin{tabular}{|c|c|c|c|}
\hline Değişken & Grup & $\mathbf{N}$ & $(\%)$ \\
\hline \multirow[t]{6}{*}{ Fiyat } & $200000 \mathrm{TL}$ altı & 6 & 10 \\
\hline & 200000-299999TL & 20 & 33 \\
\hline & 300000-499999TL & 32 & 53 \\
\hline & 500000-749999TL & 0 & 0 \\
\hline & 750000-1000000TL & 2 & 3 \\
\hline & 1000000 TL üzeri & 0 & 0 \\
\hline \multirow[t]{4}{*}{ Konut satın alınan kuruluşlar (birden fazla seçenek belirtilebilir) } & Kendi firmaları tarafından yüz yüze & 55 & 92 \\
\hline & İnternet & 40 & 67 \\
\hline & Uluslararası aracı firma & 25 & 41 \\
\hline & Uluslararası emlakçı & 15 & 25 \\
\hline \multirow[t]{4}{*}{ Trabzon'da bulunmadıkları dönemde kullanımı (birden fazla seçenek belirtilebilir) } & Kendi ülke vatandaşlarına kiraya verme & 10 & 16 \\
\hline & Türkiye vatandaşlarına kiraya verme & 8 & 13 \\
\hline & Diğer ülke vatandaşlarına kiraya verme & 4 & 7 \\
\hline & Boş bırakma & 40 & 67 \\
\hline
\end{tabular}


konutlarını peşin, yerli müşterilerin \%79'u ise kredi ile satın aldıkları ifade etmiştir. Aynı zamanda bu durum yerlilerin alım gücünün yabancılardan daha az olduğunun da bir göstergesidir. Araplar konutlarını sırasıyla inşaat firmalarından yüz yüze, internetten, uluslararas1 arac1 firmalar ve uluslararası emlakçılardan satın aldıklarını belirtmişlerdir. Yerelde konut piyasasında daha önce bulunmayan uluslararası emlakçıların ve aracı firmaların dâhil olduğunu görmekteyiz.

“Ana vatanınıza döndügünüzde Trabzon'daki konutunuzu nasıl kullanıyorsunuz" sorusuna, Arapların üçte biri kiraya verdiklerini ve genellikle de Türkiye Cumhuriyeti vatandaşı olmayanlara kiraladıklarını belirtmişlerdir (Tablo 8). Aynı zamanda yabancılar konut sahibi olmadan önce Trabzon'a geldiklerinde otelde (\%43), kiralık konutta (\%37) ve apartta (\%39) kaldıklarını belirtmişlerdir. Buradan hareketle, yabancıların konut ediniminin Trabzon'da turizm sektöründe konaklama başta olmak üzere diğer alanlardaki gelirlerinin azalmasına neden olduğunu söyleyebiliriz.

Ankete katılan inşaat firmalarına, Trabzon'da 2012 y1lı sonrasında konut fiyatlarındaki değişimini ve bunun nedenlerini değerlendirmeleri amacıyla yöneltilen açık uçlu soruya, tamamı konut fiyatlarının arttığı cevabını vermiştir. Bunun nedenleri içerisinde $\% 78$ oranıla yabancıların talebi (yabancıların gelmesi, yabancıların akını ve yabancı yatırımcılar) öne çıkmaktadır. Bu bulgular ilgili alan yazısında, yabancıların ikinci konut talebinin kente olumsuz ekonomik etkisi olarak belirtilen, artan konut fiyatlarının Trabzon'da da deneyimlendiğinin göstergesidir. $\mathrm{Bu}$ artış, konut fiyatlarını "yerel halkın alım gücünün üzerinde" bir hale getirdiğinin altı çizilmektedir ve bu kişilerin konut piyasasından dışlanmasına da bir örnektir.

“Yabanclların Trabzon'dan konut edinmesinin kente ne tür etkilerinin olduğunu düşünüyorsunuz" açık uçlu sorusuna inşaat firmasındaki yetkililerin $\% 85$ 'i pozitif etkili, $\% 15$ ' $\mathrm{i}$ ise negatif etkili cevabını vermişlerdir. Sadece yerli müşterisi olan inşaat firmaları negatif etkilerden söz ederken, hem yerli hem de yabancı müşterisi olan firmalar iki tür etkiyi dile getirmektedir. Katılımcılar tarafından konut fiyatlarının yüksek oluşu en sık tekrarlanan olumsuz etki; inşaat sektörü başta olmak üzere diğer iş kollarında ekonomik getiri sağlaması ise en fazla dile getirilen pozitif etkidir. Yabancı müşterisi olan firmalar, yerel halkın Araplar ile aynı yerde yaşamaktan şikâyetçi oluşunu, "her şeyin fiyatının artışı" nı (gıda, taşıma, yeme-içme ücretleri, vb.), Trabzonluların alım gücünün üzerinde konut fiyatlarının olmasını ve kültürel farklılıkların yaşanmasını negatif etkiler olarak sıralamaktadır. Firmalar "uluslararası Trabzon yaratıldığını" ve yabancıların özellikle kentte doğayı sevdiklerinin altını çizmektedirler.

\section{TARTIŞMA VE SONUÇ}

$\mathrm{Bu}$ çalışma, ülkemiz coğrafyasında yabancıların konut edinimine yönelik karşılıklılık ilkesinin 2012 y1lında kaldırılmasıyla başlayan dönemde konut edinen yabancıların uyruklarının ve demografik yapılarının değiştiğini ortaya koymaktadır. 2012 yılı öncesinde Türkiye'de konut edinen yabancılar genellikle İngiltere, Almanya, Hollanda gibi Avrupa ülkeleri vatandaşları olmasına rağmen, Trabzon'da Suudi Arabistan ve Kuveyt başta olmak üzere Arap ülkeleri vatandaşları ikinci konut edinmektedir. Arapların en az bir, en fazla sekiz çocuğu vardır ve ortalama hane halkı büyüklüğü 4,6' dır.Bu kişiler, evli, çalışır durumda, üniversite ve üzeri eğitim seviyesine sahiptir.

Arapların kentte ikinci konut taleplerinin nedenleri arasında Trabzon'un güvenli bir kent olarak görmeleri öne çıkmaktadır. Bu durum, Türkiye'de 2012 öncesi ikinci konut edinen yabancıların; iklim, bölgeye hayranlık, rahat yaşam koşulları vb. nedenlerinden farklıdır. İlgili alan yazısında, yabancıların ikinci konut talebini belirleyen etmenlerden siyasal, kültürel ve sosyal gelişmelerle ilişkilendirilebilir. Arapların ana vatanlarının olduğu bölgede siyasi istikrarsızlık, vatandaşlarının ikinci konut talebinde güvenlik arayışının bir nedeni olarak gösterilebilir. Küresel göç bağlamında, Arap dünyasındaki siyasal belirsizlikler itme faktörü, Türkiye'nin konut sahibi yabancılara iki yıla kadar aile ikamet izni hakkı tanıması çekme faktörü olarak değerlendirilebilir. Arapların, ana vatanlarındaki toplumsal ve siyasal gelişmelerden ötürü isteğe bağlı ya da zorunlu göç etmeleri durumunda, Türkiye'de ikinci konut sahibi kişilerin, çoğunluğu Trabzon'u alternatif bir yerleşim alanı olarak görmektedirler. Böyle bir durumda, Arapların hane halkı büyüklüğünün 4,6 kişi, Trabzon'da ise bunun 3,3 kişi olduğu dikkate alınırsa, ciddi bir nüfus artı̧ı kaçınılmaz olur.

İlgili alan yazısında ve ülkemizdeki diğer örneklerde görüldüğü gibi, Trabzon'da da yabancıların konut ediniminde, hem kentin hem de konutun tercihinde ulaşım imkanları önemli bir etkendir. İkinci konut talebinde tanıdık ve akrabalarla bir arada yaşama isteği Trabzon'da da benzer şekilde deneyimlenmektedir. Yabancıların bir arada kümeleşme isteğiyle, yerliler için yabancıların yaşam alanlarında varlığının konut tercihindeki olumsuz etkisi birlikte değerlendirildiğinde, iki grup arasındaki ayrışma isteği dikkati çekmektedir. Ancak bu ayrışma isteği Araplar tarafından kendi akraba tanıdıklarıyla bir arada yaşama olarak kendini gösterirken, Trabzonlular için 
yabancılarla bir arada yaşamayı istememek olarak karşımıza çıkmaktadır. Bu durum yabancıların ikinci konut ediniminin sosyal ayrıştırıcı etkisinin göstergesidir. Yabancıların \%87'lik kesimi başkalarına Trabzon'dan konut alınmasını tavsiye edebilecekleri bulgusu dikkate alındığında, hem kente olan ilginin devam edeceği hem de bu ayrışmanın giderek artmasını beraberinde getirecektir. Kentin sosyal yapısı açısından bu ayrıştırıcı etkinin ortadan kaldırılması gerekmektedir. Kent sosyolojisi alanında bu konuyu daha ayrıntılı ele alan çalışmalar yapılarak, yerli halkın yabancılar ile bütünleşmesini sağlama yönünde kentsel politikaların oluşturulması kritik önem sahiptir.

Trabzon'da yabancıların konut edinimi ekonomik açıdan iki olumsuz etki oluşturmuştur. Bunlardan ilki, kentteki konut fiyatlarının artması ve bunun yerel halkın alım gücünü zorlamasıdır. Araplar, konutlarını bittikten sonra peşin, yerel halk ise projeler henüz başlamadan (topraktan) kredi kullanarak veya taksitle satın almaktadır. Ekonomik açıdan ikinci olumsuz etki ise, Türkiye'deki diğer bölgelerindeki örneklerle benzer şekilde, turizm gelirlerinin azalmasıdır. Kenti turistik amaçlı geldiklerinde otellerde konaklayan Araplar, ikinci konut sahibi olduktan sonra evlerinde kalmakta ve burada bulunmadıkları dönemlerde de konutlarını yabancılara kiraya vermektedirler. Ekonomik açıdan tek olumlu etki ise, yabancıların ikinci konut ediniminin yerelde yeni bir istihdam alanı yaratmasıdır. Araplar konutlarını, internetten, uluslararası aracı firmalardan ve uluslararası emlakçılardan satın aldıkları bilgisinden hareketle, yerelde konut piyasasında daha önce bulunmayan bu aktörler sürece dâhil olmuştur.

Türkiye'de 2012 yılından sonraki dönemde yabancıların ikinci konut talebini ve bunun kentlere etkilerini ortaya koyan bu çalışma, belirtilen talebin yönlendirilmesinde ve etkilerinin kontrol altına alınmasında yol gösterici olacaktır. Konut politikaları üreten ve konut alanlarını planlayan yerel yönetimlerin uluslararası düzeydeki konut talebinin sosyal ve ekonomik açıdan yaratmış olduğu doğrudan ve dolaylı olumsuz etkilerini giderici; olumlu etkilerini arttırıcı kararlar alması ve uygulaması hayati öneme sahiptir. Unutulmamalıdır ki uluslararası düzeyden gelen bu tür talepler ekonomik olarak yatırımcıya katkı sağlasa da sürekliliğinin garantisi bulunmamaktadır. Günümüzde de deneyimlemekte olduğumuz pandemi gibi tahmin edilmesi güç gelişmeler, uluslararası ilişkileri kesintiye uğratmakta ve talebi olumsuz yönde etkilemektedir. Sonuç olarak sürdürülebilir toplumlar ve yaşanabilir kentsel çevreler oluşturmak için yerel dinamikleri dikkate alarak yabancıların ikinci konut talebine yönelik arz gerçekleştirilmelidir.
Hakem Değerlendirmesi: Dış bağımsız.

Çıkar Çatışması: Yazarlar çıkar çatışması bildirmemiştir.

Finansal Destek: Yazarlar bu çalışma için finansal destek almadığını beyan etmiştir

Peer-review: Externally peer-reviewed.

Conflict of Interest: The authors have no conflict of interest to declare.

Grant Support: The authors declared that this study has received no financial support.

\section{KAYNAKÇA/REFERENCES}

Avc1, M., Avc1, U. ve Şahin, F. (2008). Sosyal ve ekonomik yönüyle Fethiye'ye yabancı göçü. Muğla: Fethiye Sanayi ve Ticaret Odası.

Bakırcı, S. (2007). Yabancıların ikinci konut talebinin fiziksel çevreye etkisi: Dalyan örneği. (Yüksek Lisans Tezi). Gazi Üniversitesi Fen Bilimleri Enstitüsü, Ankara.

Bell, M. \& Ward, G. (2000). Comparing temporary mobility with permanent migration.Tourism Geographies, 2(1), 87-107. https:// doi.org/10.1080/146166800363466

Bohlin, M. (1982). Second homes in the regional economy: where the cottagers Money go. Geografiskaregionstudier 14, Kulturgeografiska institutionen, Uppsala.

Casado-Diaz M. A. (1999). Socio-demographic impacts of residential tourism: a case study of Torrevieja, Spain. International Journal of Tourism Research, 1(4), 223-237. https://doi.org/10.1002/ (SICI)1522-1970(199907/08)1:4<223::AID-JTR153>3.0.CO;2-A

Casado-Diaz, M. A., Kaiser, C. \& Warnes, A. M. (2004). Northern european retired residents in nine southern european areas: characteristics motivations and adjustment. Ageing and Society, 24(03), 353-381. https://doi.org/10.1017/S0144686X04001898

Casado-Diaz, M. A. (2009). Social capital in the sun: Bonding and bridging social capital among British retirees. In M. Benson \& $\mathrm{K}$. O'Reilly (Eds.), Life style migration: expectations, aspirations and experience. London, UK: Ashgate.

Castles, S. \& Miller, M. J. (1993). Theage of migration: international population movements in the modern World. London: Macmillan.

Çelikel, A. (2017). Yabancılar Hukuku (23.bs.). İstanbul: Beta Basım.

Erdoğanaras, F., Güzey, Ö., Görer Tamer, N., ve Yüksel, Ü. (2005). Yabancıların mülk edinmesi ve yabancı orta yaş üzeri emekli göçünün kıyı yerleşmelerinde etkisi: Türkiye örneği. Planlamada Yeni Politika ve Stratejiler 29. Dünya Şehircilik Günü Kolokyumu, Türkiye (s. 119-132).

Giddens, A. (2012). Sosyoloji. C. Güzel (Eds.), (1.bs.), İstanbul: Kırmız1 Yayınlar1

Green, G. P., Marcouiller, D., Deller, S., Erkkila, D. \& Sumathi, N. R. (1996). Local dependency, land use attitudes, and economic development; comparsion between seasonal and permanent residents.Rural Sociology, 61(3), 427-445.

Gündüz, E. (2003). Tatil amaçl ikinci konutların fiziksel ve sosyal yapıya etkileri Mahmutlar örneği. (Yüksek Lisans Tezi). Selçuk Üniversitesi Fen Bilimleri Enstitüsü, Konya. 
Hall, C. M. \& Müller, D. K. (Ed.). (2004).Tourism, mobility and second homes between elite landscape and common ground. Clevedon, UK: Channel View Publications.

Harvey, D. (2008). Umut Mekanları (Z. Gambetti, Çev.). (1.bs.). İstanbul: Metis Yayınları.

Karaaslan, Ş. ve Yalçıner Erçoşkun, Ö. (2005). İkinci konutların turizme kazandırılması: Antalya/Serik-Boğazkent örneği. Gazi Üniversitesi Bilimsel Araştırma Projesi; Proje No:06/2003-81, Gazi Üniversitesi Mühendislik Mimarlık Fakültesi, Şehir ve Bölge Planlama Program1, 3-4.

Karakaya, E. ve Turan, A. H. (2006). Türkiye'de yabancı emekli göçü: Didim'in yeni sakinleri ve bölgeye ekonomik etkileri. Iktisatİsletme-Finans, 21(246), 122-132.

Keleş, R. (1998). Kent bilim terimleri sözlüğü, (2.bs). Ankara: İmge Yayınevi.

Keskinok, Ç., Şahin Güçhan, N. ve Özgönül, N. (2005). Kalkan'ın gelişme ve koruma sorunları: tehditler, olanaklar ve çözüm önerileri. Planlama, 1, 87-104.

King, R., Warnes, T. \& Williams, A. (2000). Sunsetlives: British retirement to the mediterranean. New York: Berg Publishers.

Mizan, G. (1994). Turizm ve ikinci konut gelişiminin doğal çevre üzerindeki etkilerinin incelenmesi: Dilek Yarımadası ve yakın çevresi örneği. (Yüksek Lisans Tezi). İstanbul Teknik Üniversitesi Fen Bilimleri Enstitüsü, İstanbul.

Nudral1, F. Ö. (2007). The experiences of citizens in Didim, a coastal town in Turkey: a case study of lifestyle migration. (Doktora Tezi). Ortadoğu Teknik Üniversitesi Sosyal Bilimler Enstitüsü, Ankara.

Okyavuz, M. (2005). Küresel Ekonomi ve Göç, C. Karadeli (Der.), Küreselleşme ve Alternatif Küreselleşme kitabı içinde (s. 241-257). Ankara: Phoenix Yayınevi

O'Reilley, K. (2001). The British on the Costa del Sol: transnational communities and local identities. London, UK: Routledge.

Rodriguez, V., Fernandez-Mayoralas, G. \& Rojo, F. (1998). European retirees on the Costa del Sol: a cross-national comparison. International Journal of Population Geography, 4(2), 183-200. https://doi.org/10.1002/(SICI)1099-1220(199806)4:2<183::AIDIJPG101>3.0.CO;2-8
Rodriguez, V. (2001). Tourism as a recruiting post for retirement migration. Tourism Geographies, 3(1), 52-63. https://doi. org/10.1080/14616680010008702.

Sürmeli, M. (2003). Türkiye'de 1990 sonrası uygulanan konut politikaları ve sorunları. (Yüksek Lisans Tezi). Selçuk Üniversitesi Sosyal Bilimler Enstitüsü, Konya.

Şahin, Y. (2010). Kentleşme Politikast. (1.bs.). Trabzon: Murathan Yayınevi.

Tamer Görer, N., Erdoğan Aras, F., Güzey, Ö. ve Yüksel, Ü. (2006). Effects of second home development by foreign retiremen tmigration in Turkey, 42nd ISoCaRPCongress sunulan bildiri, Istanbul. http://www.isocarp.net/Data/case studies/790.pdf

Tapu Kadastro Genel Müdürlüğü (2017). Trabzon'dan Bağımsız Bölüm Edinen Yabanc1 Sayı Ve Uyruk İstatistikleri

United Nation. (2012). International Migration Report 2002, Yayın No: ST/ESA/SER.A/220, NY.

URL-1. (2012, 8 Ağustos). Türkiye'den tapu alabilecek ülkelerin listesi. Erişim Adresi: https://www.antalyahomes.com.tr/tasinmaz-satinalabilecek-ulkelerin-listesi?\%20page $=2$ (S.E.T. 22.02.2021)

URL-2. (2012, 10 Ağustos). Mütekabiliyetten Hangi Ülkeler Şartsız Yararlanacak? Milliyet. Erişim Adresi: https://www.sondakika.com/ haber/haber-mutekabiliyetten-hangi-ulkeler-sartsiz-3853421/ (S.E.T. 22.02.2021)

Urry, J. (2000). Sociology beyond societies mobilities for the twentyfirst century. London, UK: Routledge.

Y1ldırım, M. T. (1992). İkinci konutların turizm sektörüne entegrasyonu. (Yüksek Lisans Tezi). Gazi Üniversitesi Fen Bilimleri Enstitüsü, Ankara.

Y1lmaz Bayram, Z. ve Bayram, Y. (2016). Küreselleşen konut sektöründe yabancıların etkisi: Trabzon örneği. II. Uluslararası Kent Araştırmaları Kongresi Küresel ve Yerel Arasinda Kentler: Stratejiler, Firsatlar ve Sorunlar Bildiriler Kitabı. 89-111. 